\title{
Phytoplankton blooms on the western shelf of Tasmania: evidence of a highly productive ecosystem
}

\author{
J. Kämpf \\ School of the Environment, Flinders University, Adelaide, Australia \\ Correspondence to: J. Kämpf (jochen.kaempf@ flinders.edu.au)
}

Received: 4 September 2014 - Published in Ocean Sci. Discuss.: 15 September 2014

Revised: 27 November 2014 - Accepted: 27 November 2014 - Published: 5 January 2015

\begin{abstract}
Satellite-derived chlorophyll $a$ data using the standard NASA-OC3 (ocean colour) algorithm are strongly biased by coloured dissolved organic matter and suspended sediment of river discharges, which is a particular problem for the western Tasmanian shelf. This work reconstructs phytoplankton blooms in the study region using a quadratic regression between OC3 data and chlorophyll fluorescence based on the fluorescence line height (FLH) data. This regression is derived from satellite data of the nearby Bonney upwelling region, which is devoid of river influences. To this end, analyses of 10 years of MODIS-aqua satellite data reveal the existence of a highly productive ecosystem on the western Tasmanian shelf. The region normally experiences two phytoplankton blooms per annum. The first bloom occurs during late austral summer months as a consequence of upwelling-favourable coastal winds. Hence, the western Tasmanian shelf forms a previously unknown upwelling centre of the regional upwelling system, known as Great South Australian Coastal Upwelling System. The second phytoplankton bloom is a classical spring bloom also developing in the adjacent Tasman Sea. The author postulates that this region forms another important biological hot spot for the regional marine ecosystem.
\end{abstract}

\section{Introduction}

Physical processes that enrich the euphotic zone with nutrients are principal agents of coastal phytoplankton blooms. Such processes include upwelling, storm-induced mixing, internal waves and river plumes. Despite elevated nutrient levels, high turbidity levels in river plumes can suppress diatom growth (e.g. Chen et al., 2003). Except for the situa- tion of coastal upwelling, vertical density stratification generally supports phytoplankton production, in particular when the surface mixed layer is relatively shallow and coincides with the euphotic zone. This situation supports the development of the spring bloom, which is characteristic of temperate North Atlantic, sub-polar and coastal waters (Mann and Lazier, 2006).

The southern shelves of Australia host a large seasonal coastal upwelling system (Kämpf et al., 2004; Kämpf, 2010). In response to south-easterly coastal winds, upwelling events occur in austral summer months (December to April). This upwelling system, referred to as the Great South Australian Coastal Upwelling System, consists of three upwelling centres (Fig. 1): the long-known Bonney upwelling (Rochford, 1977; Lewis, 1981; Schahinger, 1987; Griffin et al., 1997) along the so-called Bonney coast, and an upwelling centre off the southern tip of the Eyre Peninsula (Kämpf et al., 2004). The latter region plays a vital role in the life cycles of sardine (Sardinops sagax), anchovy (Engraulis australis), and southern bluefin tuna (Thunnus maccoyii) (Ward et al., 2006). Another smaller upwelling centre develops occasionally off the southwest coast of Kangaroo Island (see Kämpf et al., 2004).

This study focusses on the western Tasmanian shelf Throughout the year, the Zeehan Current runs southeastward confined to the shelf break along the continental shelf edge of western Bass Strait and western Tasmania (Cresswell, 2000). This current is the extension of the South Australian Current, which itself is the continuation of the Leeuwin Current (Ridgway and Condie, 2004), but seasonally also entrains warm water formed during summer months on the shelves of the western Great Australian Bight (Herzfeld, 1997). Currents within Bass Strait are created by tides, winds, incident continental shelf waves and 


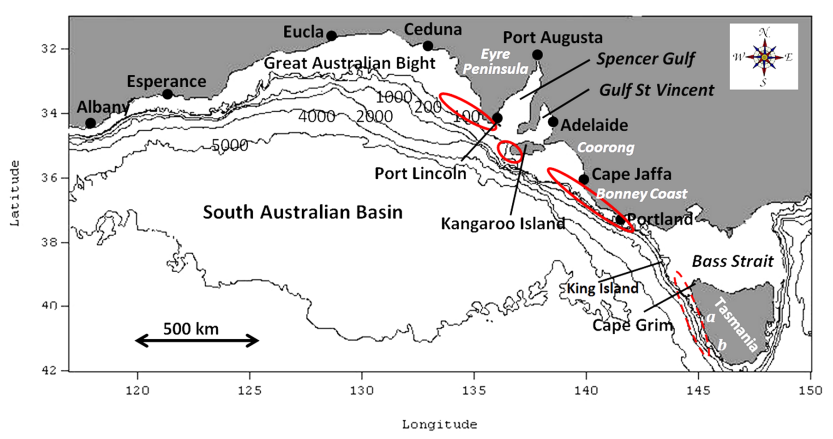

Figure 1. The geography of Australia's southern shelves. Isobath depths are in metres. Solid-line ellipses display known locations of coastal upwelling centres. The dashed-line ellipse highlights the region investigated in this paper. Letters $a$ and $b$ indicate the locations of the mouths of the Macquarie Harbour estuary and the Davey River.

density-driven flows (e.g. Sandery and Kämpf, 2005). Bass Strait is relatively shallow $(\sim 50-70 \mathrm{~m})$ and the main pathway of currents is generally eastward (Sandery and Kämpf, 2007). Prominent oceanographic features of Bass Strait are the existence of tidal mixing fronts on both sides of the strait (Sandery and Kämpf, 2005), and the wintertime formation of a density-driven overflow on the eastern side of the strait in the vicinity of the Bass Canyon, known as the Bass Strait Cascade (Tomczak, 1985). Based on sparse field data, Gibbs et al. (1986) concluded that nutrient levels in Bass Strait are low overall $(<1 \mu \mathrm{M}$ in nitrate) except along the eastern edge where nutrient concentrations reach high levels (up to $7 \mu \mathrm{M}$ in nitrate) in winter. According to these authors, chlorophyll $a$ levels in the Bass Strait are also generally low $\left(<0.5 \mathrm{mg} \mathrm{m}^{-3}\right)$ but show the highest concentrations over the adjacent shelf, again in winter.

Earlier work (Connolly and Von der Borch, 1967) postulated that upwelling of cold sub-Antarctic waters is the main reason for the occurrence of extensive temperate carbonates on the southern Australian shelves. Isotopic studies (e.g. Wass et al., 1970) validated this upwelling model for the formation of cold-water carbonates. Interestingly, modern cold-water carbonate is also the predominant sediment on the western Tasmanian shelf (Rao and Green, 1983). Isotopebased findings of Rao and Adibi (1992) demonstrate upwelling seawater as the main process responsible for the formation of carbonates in western Tasmania. Motivated by the findings of Rao and Adibi (1992), this work explores phytoplankton blooms on the western Tasmanian shelf and their underlying physical processes.

\section{Methodology}

This work is based on satellite data, coastal wind data and time series of river discharges with a focus on the western Tasmanian shelf in comparison with the Bonney upwelling region. Averages of phytoplankton-related parameters were constructed from the satellite data of predefined target areas (see Fig. 1) as the average of 10 pixel data of the highest values for Sea-viewing Wide Field-of-view Sensors (SeaWiFS), and 50 pixels of the highest values for MODIS-aqua; this corresponds to combined areas of 810 and $800 \mathrm{~km}^{2}$, respectively. Values were classified as invalid from a visual analysis of the level of cloud bias within the target areas.

Ocean colour data are based on standard blue/green ratio algorithms for chlorophyll $a$ retrieval, which can substantially overestimate phytoplankton blooms in coastal waters in the presence of coloured dissolved organic matter (CDOM or Gelbstoff) and suspended sediment (e.g. Garcia et al., 2006; Shanmugam, 2011). SeaWiFS ocean colour data are based on the OC4 (ocean colour) algorithm, whereas MODIS-aqua data are often based on the OC3 algorithm (O'Reilly et al., 2000). Two different time periods are considered. The first period (1 January 1998 to 31 December 2000), also studied by Kämpf et al. (2004), is adopted to establish initial evidence of the phytoplankton dynamics on the western Tasmanian shelf. Data have been extracted from the South East Fishery (SEF) ocean movies (David Griffin, CSIRO, http: //www.marine.csiro.au/ griffin/SEF/) based on the SeaWiFS database ( $9 \mathrm{~km}$ spatial resolution). It should be noted that of the 136 eight-day segments of OC4 data, 35 segments (26\%) are invalid for the western Tasmanian shelf due to cloud bias, mainly during austral winter-spring months. This first analysis indicates that ocean-colour-derived chlorophyll $a$ data for the study region are substantially modified by river discharges.

The fluorescence line height (FLH) is a relative measure of the amount of radiance leaving the sea surface in the chlorophyll fluorescence emission band (e.g. Xing et al., 2007). The chlorophyll $a$ fluorescence peak near $685 \mathrm{~nm}$ has been proposed as an alternative option of chlorophyll $a$ retrieval (Neville and Gower, 1977; Gordon, 1979). Many researchers have studied the relationship between chlorophyll $a$ concentration and FLH, and have found a good correlation between these properties (Maritorena et al., 2000; Gower et al., 2004; Gower and King, 2007) for relatively low chlorophyll $a$ concentrations $<9 \mathrm{mg} \mathrm{m}^{-3}$, which applies to this study. At higher chlorophyll $a$ concentrations, the fluorescence peak shifts to longer wavelengths (e.g. Gitelson, 1993).

The second, extended study period (1 January 2005 to 31 March 2014) adopts MODIS-aqua satellite data (4 km spatial resolution), provided by NASA's Giovanni project (http://disc.sci.gsfc.nasa.gov/giovanni). Standard normalised FLH data were used to reconstruct phytoplankton blooms on the western Tasmanian shelf. In the absence of suitable field data, this reconstruction is based on a regression of normalised FLH and OC3 data for the nearby Bonney upwelling region, which is devoid of noticeable river influences. The reconstructed time series of chlorophyll $a$ is then used in an event-based, nonparametric statistical analysis of phytoplankton blooms in response to possible nutrient-supply 
events, i.e. coastal upwelling events and/or river plumes. To this end, all relevant data are converted to 8-day segments in alignment with the satellite data, noting that SST data are not used in this event analysis. For the western Tasmanian shelf, $90(21 \%)$ of the total of 425 eight-day segments are unusable due to cloud bias.

Wind data from the Cape Grim weather station (see Fig. 1), provided by Australia's Bureau of Meteorology (http: //www.bom.gov.au/), were used to calculate the classical upwelling index representative for the western Tasmanian shelf. This index is based on the theoretical offshore volume transport in the surface Ekman layer and it is calculated from

$\mathrm{UI}=\frac{|\tau|}{\rho_{o}|f|} \cos \left(\alpha-\alpha^{\prime}\right)$,

where $\tau$ is wind stress, $\rho_{o} \approx 1026 \mathrm{~kg} \mathrm{~m}^{-3}$ is seawater density, $f \approx-0.9 \times 10^{-4} \mathrm{~s}^{-1}$ is the value of the Coriolis parameter at $40^{\circ} \mathrm{S}, \alpha$ is wind direction and $\alpha^{\prime}$ is average coastline orientation, taken equivalent to $160^{\circ}$ (based on the meteorological convention that $0^{\circ}$ refers to northerly winds). Small variations of $\alpha^{\prime}$ have little influence of the results (not shown). For initial comparison, we also calculated the upwelling index for the Bonney upwelling system for the period from 1 January 1998 to 31 December 2000.

River discharge data for the western coast of Tasmania are sparse. There are no stream-flow data for the Macquarie Harbour estuary, which is the largest freshwater source on the western Tasmanian shelf. The only continuous time series of relevant river discharges that the author could find is that of the Davey River, being located in the south of western Tasmania (see Fig. 1). This study assumes that the seasonal discharge pattern of the Macquarie Harbour estuary is similar to that of the Davey River. The source of river data is Tasmania's Department of Primary Industries, Parks, Water and Environment via the Water Information System of Tasmania (http://wrt.tas.gov.au/wist/ui).

The satellite data used in this study are subject to various errors including instrument and retrieval algorithm errors, errors arising from oceanic variability, and merging, gridding and analysis algorithm errors. While the accuracy of satellite SST data is generally $<1{ }^{\circ} \mathrm{C}$, chlorophyll- $a$-related satellite products are less certain. Apart from biases due to CDOM and inorganic suspended particles, ocean colour data are influenced by seabed reflection in shallow $(<20 \mathrm{~m})$ nearshore water (which is irrelevant in the context of this work) and a widely variable shape of the phytoplankton absorption spectrum depending on pigment packaging, physiological state of the cell and community composition (Sauer et al., 2012). Consequently, it has become a necessity to develop regional ocean colour algorithms rather than using the global algorithm (e.g. Volpe et al., 2007). Nevertheless, the global OC4 algorithm worked well in reproducing the range of in situ measured chlorophyll $a$ levels during an upwelling event off the southern tip of the Eyre Peninsula (Kämpf et al., 2004).

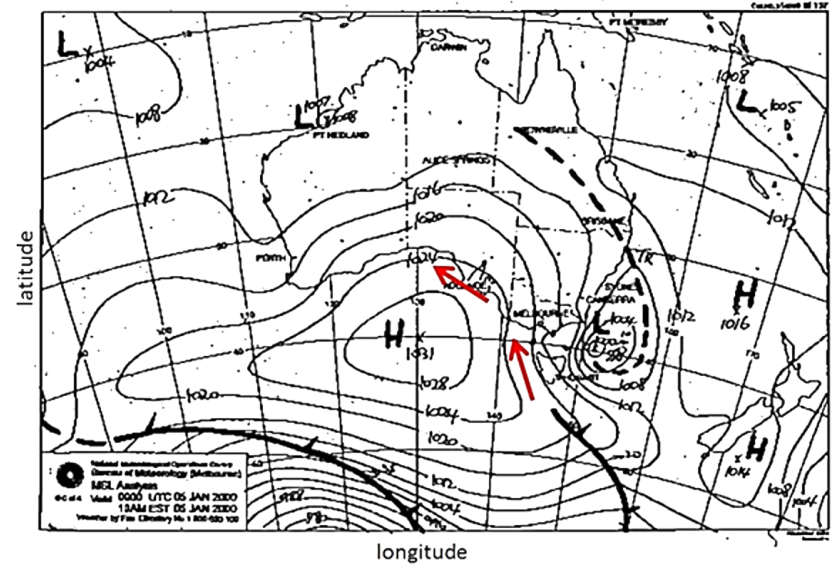

Figure 2. Mean sea level pressure for 6 January 2000, courtesy of the Bureau of Meteorology (Australia) (http://www.bom.gov. $\mathrm{au} /$ cgi-bin/charts/). Arrows indicate upwelling-favourable coastal winds, influenced by a blocking low-pressure cell over Tasmania.

On the other hand, the global OC3 and OC4 algorithms create similar ranges in chlorophyll $a$ in the South Australian upwelling centres, which justifies their unmodified use for the South Australian region (but not the western Tasmanian shelf, as will be shown with the results).

Dominant factors influencing fluorescence distributions are chlorophyll concentration, pigment packaging effects on light absorption and light-dependent energy-quenching processes (Behrenfeld et al., 2009). As far as the author is aware, there is no in situ validation of satellite FLH data for the South Australian upwelling regions. Furthermore, Giovanni's normalised FLH data, used in this study, are based on a division by the cosine of the local solar zenith angle at the time of observation. This normalisation is based on the assumption that the fluorescence signal is proportional to local solar irradiance. Recently, Gower (2014) demonstrated that this assumption is invalid and can lead to significant errors. In this work, the use of normalised FLH values as a reasonably accurate measure of chlorophyll $a$ levels (on the timescale of 8-day composites) is validated by a regression analysis between normalised FLH and OC3 data for the Bonney upwelling region (see Sect. 3.2).

\section{Results and discussion}

\subsection{Initial evidence based on SeaWiFS data (1998-2000)}

Coastal upwelling events on the southern shelves of Australia are associated with high-pressure weather systems that create south-easterly coastal winds (Kämpf et al., 2004). Due to their spatial scale and the geometry of Australia's coastline, such weather patterns can also initiate coastal upwelling on the western shelf of Tasmania. In early January 2000, for 

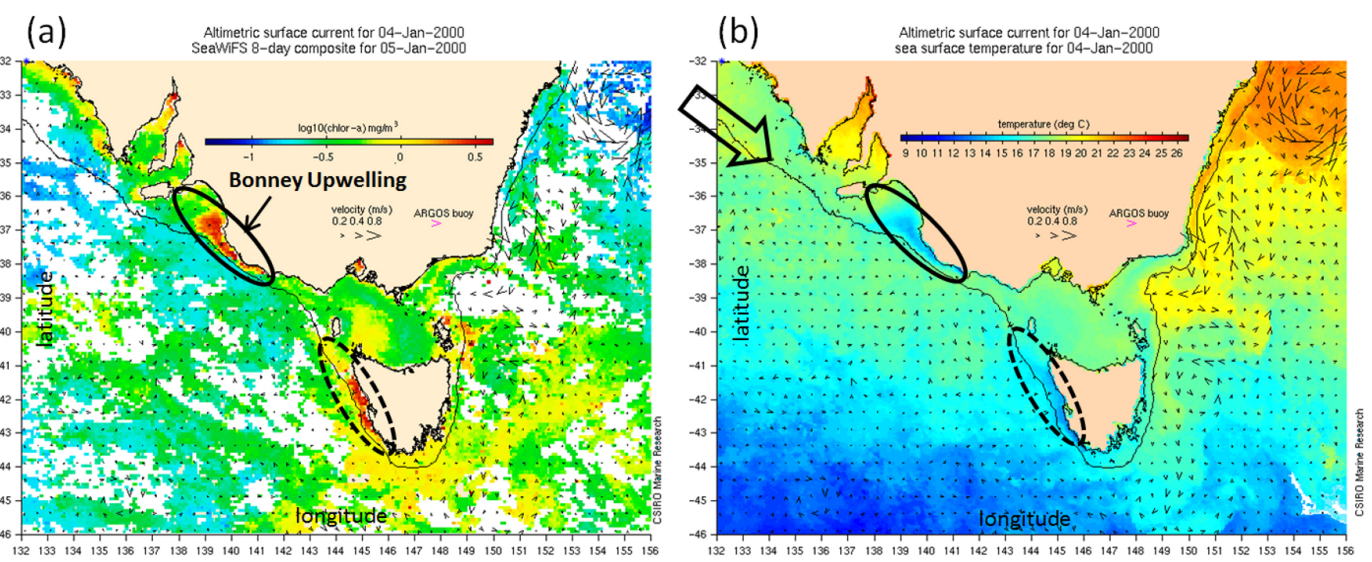

Figure 3. Occurrence of a pronounced coastal upwelling event in early January 2000, evident in satellite-derived distributions of (a) MODISOC3 chlorophyll $a$ and (b) sea surface temperature. White regions in panel (a) are missing data due to clouds. The large arrow in panel (b) indicates the pathway of the South Australian Current. Data source: South East Fishery ocean movies, David Griffin, CSIRO, http: //www.marine.csiro.au/ griffin/SEF/.

example, a high-pressure weather system developed centred over the South Australian Basin (Fig. 2). This high-pressure system became blocked by a low-pressure cell over Tasmania, triggering coast-parallel, upwelling-favourable winds along both Australia's southern shelves and the west coast of Tasmania. During this period, strong upwelling occurred in the upwelling centres on the southern shelves (Kämpf et al., 2004). During this event, chlorophyll $a$ levels on the western Tasmanian shelf attained values of $\sim 3 \mathrm{mg} \mathrm{m}^{-3}$, the same order of magnitude as those observed in the upwelling centre along the Bonney coast (Fig. 3a). Upwelling-related negative SST anomalies can be identified in both regions (Fig. 3b). While the Bonney upwelling has pronounced temperature anomalies of $2-3{ }^{\circ} \mathrm{C}$, temperature anomalies on the western Tasmanian shelf are relatively difficult to distinguish from those in the ambient ocean which are of a similar range.

The time series of the upwelling indices for both regions (Fig. 4) reveals that, similar to the upwelling centres of Australia's southern shelves, coastal winds along the west coast of Tasmania are, on average, upwelling favourable during austral summer months (December-April). This indicates that both regions share similar wind-forced upwelling characteristics. Earlier work by Kämpf et al. (2004) has overlooked this feature.

OC4 chlorophyll $a$ levels off the Bonney coast develop clear peaks during the austral summer upwelling season; chlorophyll $a$ levels on the western shelf of Tasmania attain a complex temporal structure (Fig. 5a). In particular, large discrepancies in OC4 chlorophyll $a$ levels between the regions occur in austral winter months, which is the period of enhanced river discharges (Fig. 5c).

The time series of SST (Fig. 5b) reveals intermittent warming periods from May to July (i.e. during late austral autumn and early winter). These warming events, which are more pronounced along the Bonney coast than on the western Tas-
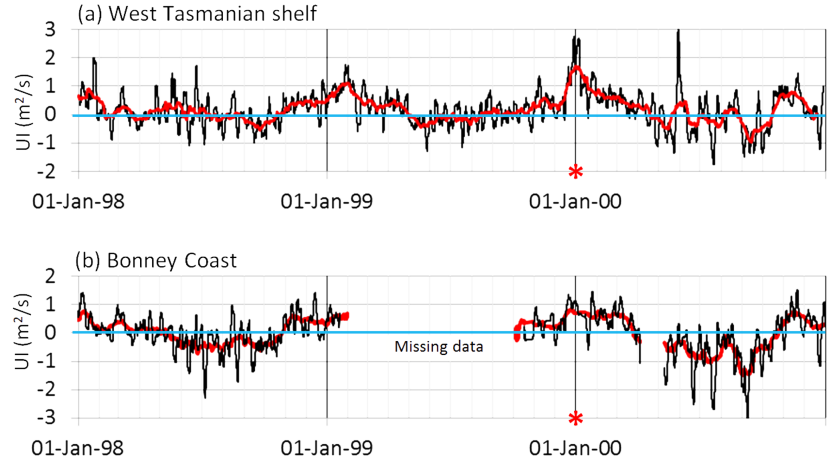

Figure 4. Time series (1 January 1998 to 31 December 2000) of the upwelling index $\left(\mathrm{m}^{2} \mathrm{~s}^{-1}\right)$ for (a) the western Tasmanian shelf and (b) the Bonney coast. Thin, black (thick, red) curves are 4-day (20day) moving averages. Stars highlight an upwelling event in early January 2000, corresponding to the spatial distributions shown in Fig. 3. Data source: Bureau of Meteorology, Australia.

manian shelf, where it appears as a shoulder on a declining head, are associated with incursions of the South Australian Current (Fig. 6 shows an example). Being of shelf origin, this current has low nutrient content (e.g. Herzfeld, 1997) and its appearance in the study regions can be identified by decreases in OC4 chlorophyll $a$ levels in each year of the time series (see Fig. 5a).

The timing of some events of elevated OC4 chlorophyll $a$ levels on the western Tasmanian shelf in October seem to coincide with the onset of spring blooms in the western Tasman Sea, where chlorophyll $a$ levels seasonally peaked in October at a level of $0.8 \mathrm{mg} \mathrm{m}^{-3}$ in the years 1998-2000 (Tilburg et al., 2002). It should be noted that the Bonney upwelling region is devoid of such spring blooms. 

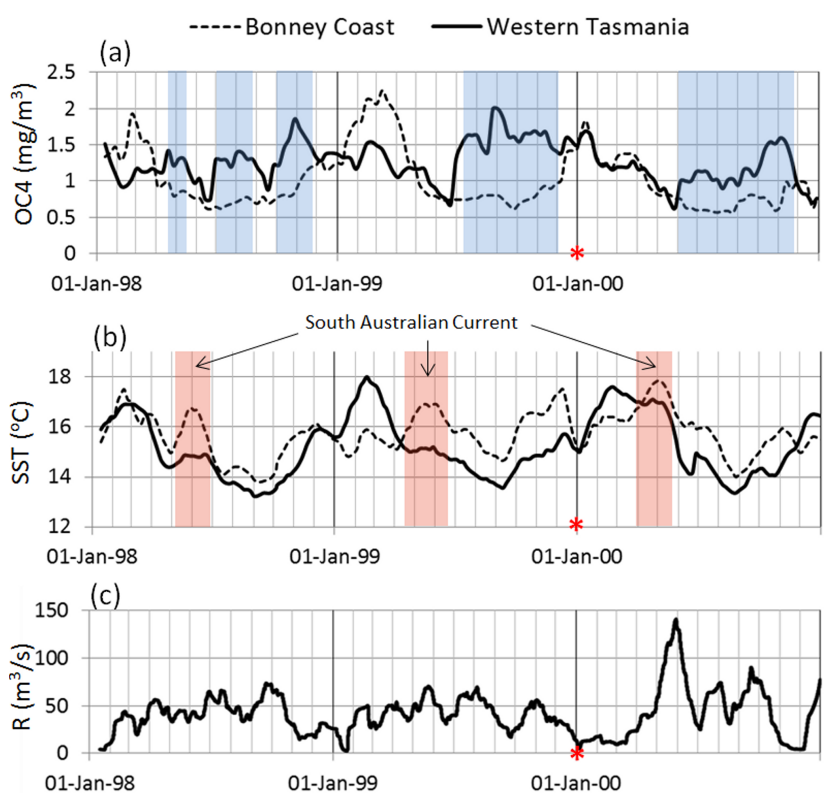

Figure 5. Time series (1 January 1998 to 31 December 2000) of satellite-derived data of (a) OC4 $\left(\mathrm{mg} \mathrm{m}^{-3}\right)$, (b) sea surface temperature $\left(\mathrm{SST},{ }^{\circ} \mathrm{C}\right)$ for the Bonney coast and the western Tasmanian shelf, and (c) discharge from the Davey River $\left(\mathrm{m}^{3} \mathrm{~s}^{-1}\right)$. Running averages over an interval of 24 days have been used for both OC4 and river discharge. A running average over 20 days has been applied to the SST data. Shaded areas of panel (a) highlight periods of substantial differences between the time series. Shaded areas in panel (b) denote intermittent warming created by the South Australian Current. Stars highlight an upwelling event in early January 2000 , corresponding to the spatial distributions shown in in Fig. 3. Data source: SEF ocean movies, David Griffin, CSIRO, Australia.

\subsection{Detailed analysis based on MODIS-aqua data (2005-2014)}

Given the absence of noticeable river influences, OC3 chlorophyll $a$ data for the Bonney upwelling region can be taken as a proxy for phytoplankton levels. The time series for this region confirms the pronounced annual periodicity of phytoplankton blooms during January-May (Fig. 7a). Average peak chlorophyll $a$ levels tend to slightly vary between the years, which reflects interannual variations of the frequency and intensity of individual upwelling events in this region. Middleton et al. (2007) speculated that the upwelling intensity is strongly modulated by ENSO events, but the satellite data shown here are devoid of any dramatic interannual variability that could be linked to ENSO variability. For instance, the moderate La Niña in 2007-2008 followed by a moderate El Niño in 2009-2010 coincided with phytoplankton blooms of similar magnitudes. Similarly, the strong El Niño in 19981999 followed by a strong La Niña in 1999-2000 did not lead to significantly different chlorophyll $a$ levels during the upwelling period (see Fig. 5a).

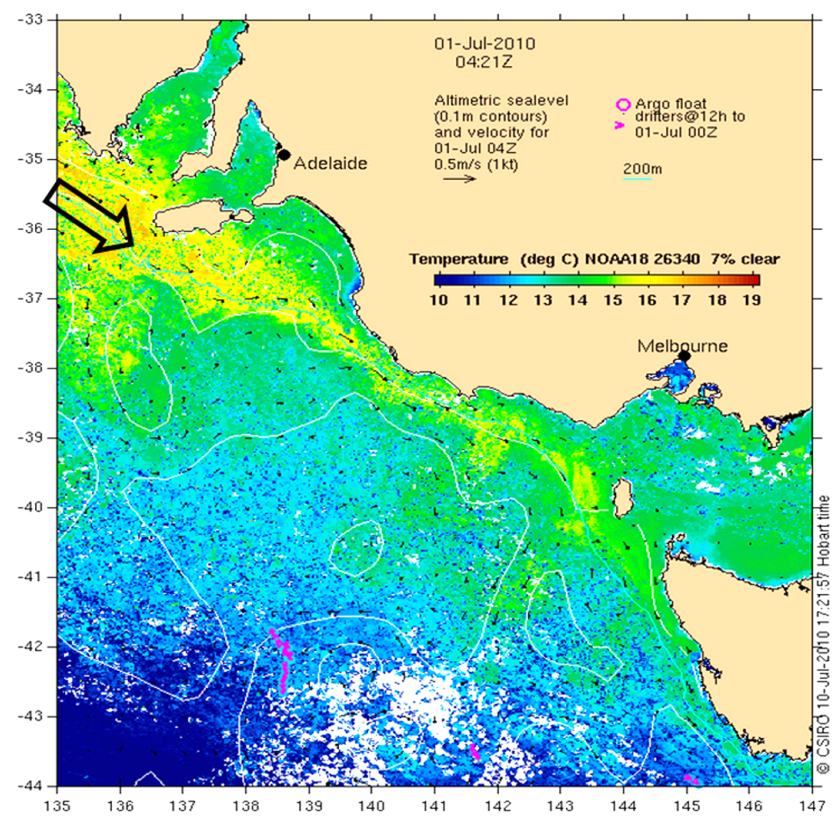

Figure 6. An example of the inflow of warm, nutrient-low South Australian Current that regularly appears along the Bonney coast and on the western Tasmanian shelf between May and July in every year. Data source: Integrated Marine Observing System (IMOS), http://oceancurrent.imos.org.au/Adelaide/2010/2010070104.html.

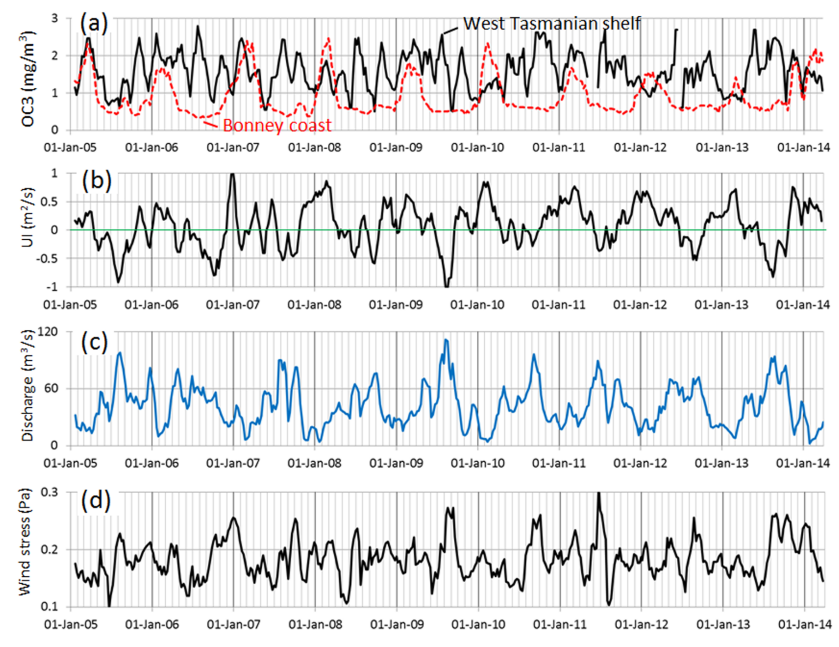

Figure 7. Time series (1 January 2005 to 31 March 2014) of (a) OC3, (b) upwelling index, (c) discharge from the Davey River and (d) wind stress. Data were first converted to 8-day segments and then smoothed with a running average over three segments. For comparison, panel (a) includes data for the Bonney coast. Data sources: NASA (Giovanni), Bureau of Meteorology (Australia) and Water Information System of Tasmania.

In contrast to the Bonney upwelling, the OC3 data on the western Tasmanian shelf vary in a highly irregular fashion and all year round (see Fig. 7a), noting that both regions attain peak values between 2 and $3 \mathrm{mg} \mathrm{m}^{-3}$. The upwelling in- 
(a)

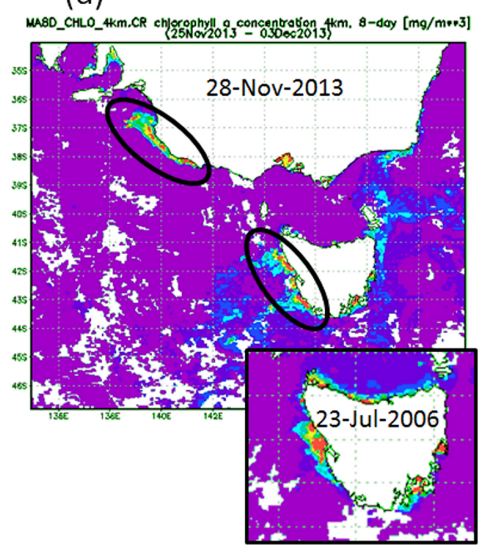

(b)

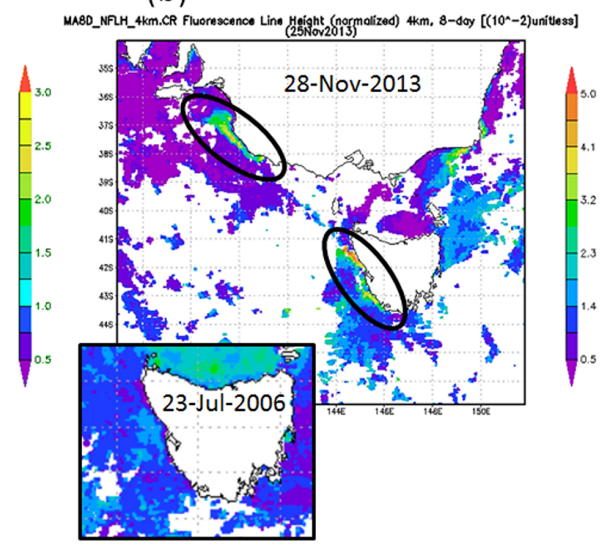

Figure 8. Snapshots of (a) OC3 $\left(\mathrm{mg} \mathrm{m}^{-3}\right)$ and (b) normalised FLH (relative units) during a major upwelling event in late November 2013. The inserts show an example of a river discharge event in late July 2006. Data source: NASA (Giovanni).

dex for the western Tasmanian shelf generally attains positive values for austral summer months (Fig. 7b). In some years, this index indicates brief upwelling events outside the summer season. For instance, the year 2007 had such an event in June, and other years (e.g. 2005 and 2013) had early upwelling-favourable wind events in November, being mirrored by individual OC3 peaks (see Fig. 7a). On the other hand, the upwelling index also indicates events of strong downwelling-favourable winds, such as in August 2009. This particular example also coincided with high wind stress, strong river flow and elevated chlorophyll $a$ levels.

Overall, the discharge from the Davey River tends to peak in austral winter-spring with markedly reduced flows during austral summer months (Fig. 7c). An exception is the year break of 2005-2006 which had a relatively strong riverine discharge occurring in December-January.

For completeness, the author also included a time series of wind stress magnitude (Fig. 7d), given that strong storms have the ability to modify phytoplankton blooms via changes in the mixed-layer depth and potential entrainment of nutrient-rich water from below. On the other hand, storms can also erode vertical structure of phytoplankton concentrations, thereby removing the surface appearance of a phytoplankton bloom. For instance, the existence of relatively strong winds $(\sim 2.5 \mathrm{~Pa})$ in January 2007 might explain relatively low surface OC3 levels in western Tasmanian coastal water although winds were upwelling favourable. It should be noted that periods of 3-7 days of relaxed winds after a brief upwelling event are deemed optimal for phytoplankton accumulation (Wilkenson et al., 2006). This relaxation effect is not explored in the context of this work.

The NASA OC3 algorithm is unreliable for the western Tasmanian shelf due to strong river influences. While it gives reasonable results in rare occasions of coastal upwelling events in the absence of river flows, it often misinterprets low productive river plumes as phytoplankton blooms, which (a) Bonney coast

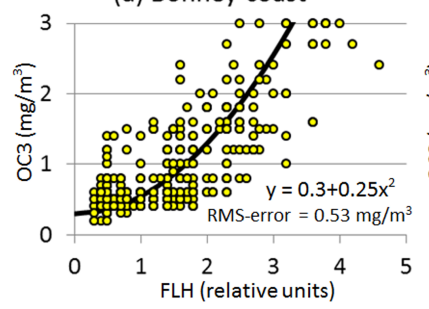

(b) West Tasmanian shelf

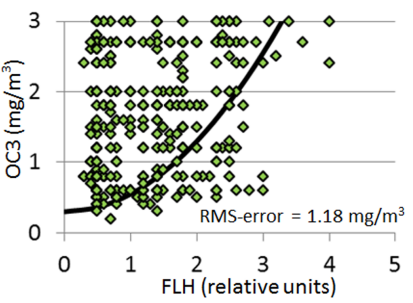

Figure 9. Correlation between OC3 values and normalised fluorescence line height (FLH), multiplied by a factor of 100, for (a) the Bonney coast and (b) the western Tasmanian shelf for the period from 1 January 2005 to 31 March 2014. Solid lines show a quadratic regression corresponding to a root mean square error (RMSE) of $0.53 \mathrm{mg} \mathrm{m}^{-3}$ for the Bonney coast data. Data source: NASA (Giovanni).

are absent in the FLH data (Fig. 8). In order to reconstruct chlorophyll $a$ levels for the western Tasmanian shelf, OC3 and FLH data can be related to each other for the Bonney upwelling region (Fig. 9a), where river influences are sparse. This comparison indicates a quadratic regression of the form of

$y=0.25+0.3 x^{2}$,

where $y$ is the reconstructed chlorophyll $a$ value, and $x$ is the FLH value (derived from the NASA Giovanni database) multiplied by 100 . The associated root mean square error (RMSE) of $0.53 \mathrm{mg} \mathrm{m}^{-3}$ is acceptable, noting that discrepancies can be attributed to absorption properties of the atmosphere and physiological variations in the phytoplankton (Xing et al., 2007). Nevertheless, the reconstructed chlorophyll $a$ time series (based on Eq. 2) agrees well with the original OC3 data (Fig. 10a). As expected, there is a mismatch between OC3 and FLH data on the western Australian shelf (Fig. 9b) attributed to river discharges. In this region, the re- 


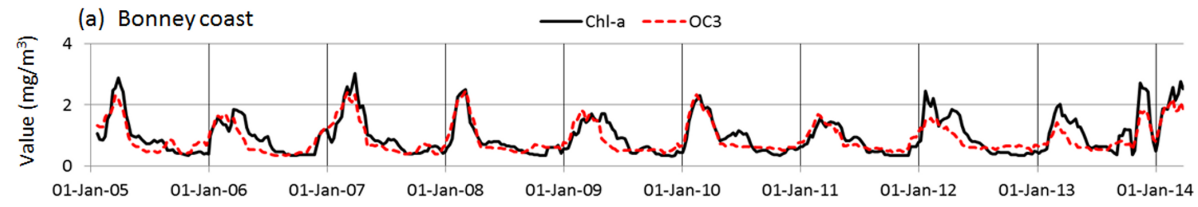

(b) West Tasmanian coast $\quad$----- raw data - smoothed data

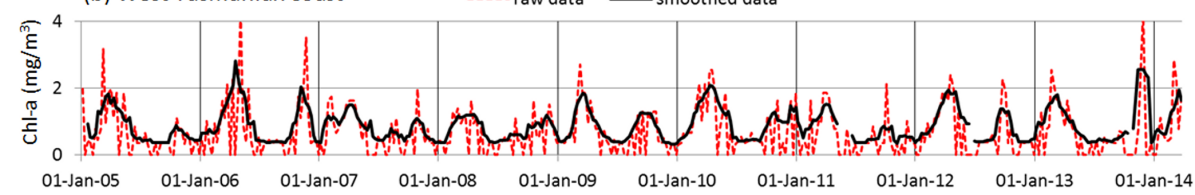

Figure 10. Reconstructed time series of chlorophyll $a$ concentrations (solid lines) from normalised fluorescence line height (FLH) according to Eq. (2) for (a) the Bonney coast and (b) the western Tasmanian shelf for the period from 1 January 2005 to 31 March 2014. Shown are running mean averages over three successive data segments. The dashed line in panel (a) shows the corresponding OC 3 data. The dashed line in panel (b) shows the raw 8-day composite data with zero values (ignored in the averaging procedure) being allocated to missing data. Data source: NASA (Giovanni).

constructed time series of chlorophyll $a$ differs substantially from that derived from the OC3 algorithm (Fig. 10b, compared with Fig. 7a). To this the end, the reconstructed time series indicates the occurrence of two phytoplankton blooms every year. The first and larger bloom occurs in late austral summer (March-April), and a second smaller bloom occurs in October coinciding with the development of spring blooms in the adjacent Tasman Sea (Tilburg et al., 2002).

\subsection{Event analysis (2005-2014)}

When using window-averaged data, a standard crosscorrelation analysis between upwelling index, OC3 or FLH data and river discharges does not give satisfactory results. Overall, the resultant correlation coefficients are insignificantly small and strongly biased by data smoothing and interpolation. Instead of this, statistically more relevant information can be derived from an event-based analysis, whereby all relevant data are averaged onto 8-day data segments. Each data segment is defined as an individual event. The underlying assumption is that phytoplankton blooms follow within $\sim$ 3-7 days after a nutrient-supply event. This implies that there is a relatively high probability that both the physical event and the ecological response occur within the timescale (8 days) of a data segment. This assumption is consistent with observational evidence (Wilkerson et al., 2006). Data segments biased by cloud cover are referred to as invalid events in the following.

This approach, for instance, returns histograms of (reconstructed) chlorophyll $a$ ranges for the study region in comparison with the Bonney upwelling region (Fig. 11). Higher levels $>1.5 \mathrm{mg} \mathrm{m}^{-3}$ can be interpreted as phytoplankton blooms. Such levels are found off the Bonney coast $\sim 18.4 \%$ of time, which is equivalent to roughly 67 days per year. In the study region, high chlorophyll $a$ levels $>1.5 \mathrm{mg} \mathrm{m}^{-3}$ occurred $14.6 \%$ of time, which corresponds to around 53 days per year. Stronger phytoplankton blooms of

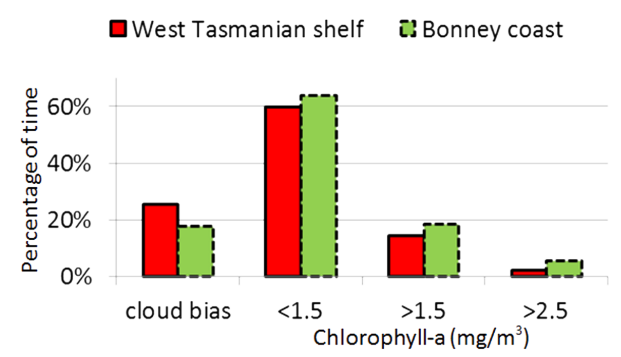

Figure 11. Event analysis. Histogram of 8-day segments for the period from 1 January 2005 to 31 March 2014 that fall within certain ranges of chlorophyll $a$ concentrations for the western Tasmanian shelf and the Bonney coast. The result is expressed as time percentage with reference to the entire time period. Cloud bias refers to missing data.

chlorophyll $a$ concentrations $>2.5 \mathrm{mg} \mathrm{m}^{-3}$ occurred $5.4 \%$ of time or 19.8 days per year off the Bonney coast and $2.4 \%$ of time or 8.6 days per annum on the western Tasmanian shelf.

When grouping data segments into different intervals of upwelling index and river discharge, the largest number of records exists for large values of the upwelling index $>0.25 \mathrm{~m}^{2} \mathrm{~s}^{-1}$ in the presence of relatively low river discharge $<25 \mathrm{~m}^{3} \mathrm{~s}^{-1}$ (Table 1). This criterion returns 101 out of a total of 316 valid events $(\sim 32 \%)$ and reflects austral summer conditions. On the other hand, a relatively large number of valid events exist for stronger river discharges $>50 \mathrm{~m}^{3} \mathrm{~s}^{-1}$ and negative values of the upwelling index $<-0.25 \mathrm{~m}^{2} \mathrm{~s}^{-1}$, returning 46 events out of 316 valid events $(\sim 15 \%)$. This criterion corresponds to periods of enhanced river discharges in austral winter and spring months when stronger northerly wind events occur (see Fig. 7). The other intervals considered have statistically satisfactory population sizes between 9 and 29 valid events.

Invalid events due to cloud bias occur for all parameter intervals considered (Table 2). The fraction of in- 
Table 1. Number of valid events of the time series (1 January 2005 to 31 March 2014) grouped according to different intervals of upwelling index (UI) and river discharge $(R)$.

\begin{tabular}{lrrrrr}
\hline$\downarrow R\left(\mathrm{~m}^{3} \mathrm{~s}^{-1}\right) / \mathrm{UI}\left(\mathrm{m}^{2} \mathrm{~s}^{-1}\right) \rightarrow$ & $<-1 / 4$ & $-1 / 4$ to 0 & 0 to $+1 / 4$ & $>+1 / 4$ & all UI \\
\hline$<25$ & 9 & 18 & 21 & 101 & 149 \\
25 to 50 & 16 & 13 & 22 & 29 & 80 \\
$>50$ & 46 & 11 & 15 & 15 & 87 \\
all $R$ & 71 & 42 & 58 & 145 & $\Sigma=316$ \\
\hline
\end{tabular}

(a) Average chlorophyll-a concentration $\square>1 / 4 \quad \square 0$ to $1 / 4 \quad \square-1 / 4$ to $0 \quad \square<-1 / 4$

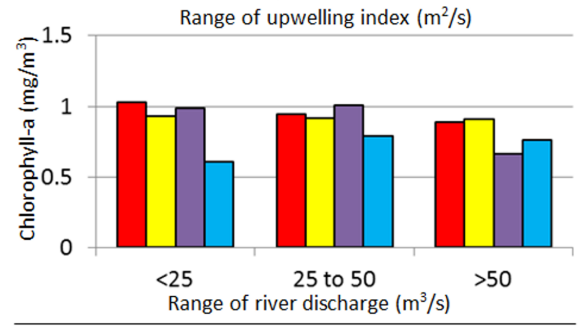

(b) Percentage of events with chl-a $>1.5 \mathrm{mg} / \mathrm{m}^{3}$ $\square>1 / 4 \quad \square 0$ to $1 / 4 \quad \square-1 / 4$ to $0 \quad \square<-1 / 4$ Range of upwelling index $\left(\mathrm{m}^{2} / \mathrm{s}\right)$

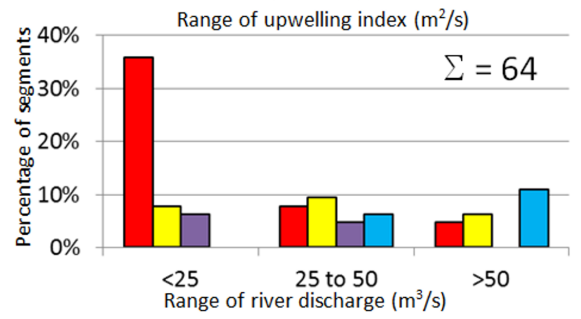

Figure 12. Event analysis of the time series (1 January 2005 to 31 March 2014). (a) Average chlorophyll $a$ values based on data segments that fall into certain intervals of upwelling index and discharge from the Davey River. The total number of segments is 316. (b) Number of data segments of chlorophyll $a$ concentration $>1.5 \mathrm{mg} \mathrm{m}^{-3}$, grouped as in panel (a). In total, 64 of the 316 data segments satisfy this condition.

valid to total events is greater in times of enhanced river discharges $>50 \mathrm{~m}^{3} \mathrm{~s}^{-1}$ for which 52 out or the total of 139 events (or $\sim 37.5 \%$ ) are invalid. In contrast, only 28 out of 177 events $(\sim 15.8 \%)$ are invalid for events with river discharges $<25 \mathrm{~m}^{3} \mathrm{~s}^{-1}$.

Consistent with the aforementioned weak crosscorrelations between parameters, average chlorophyll $a$ concentrations are of the same order of magnitude in each parameter interval considered (Fig. 12a). This implies, for instance, that stronger upwelling-favourable winds do not always create phytoplankton blooms. The only exception is a noticeable reduction of chlorophyll $a$ concentration in austral winter months (see Fig. 7b), which coincides with strong river discharges and downwelling-favourable winds.

With a focus on events of phytoplankton blooms of chlorophyll $a$ concentrations $>1.5 \mathrm{mg} \mathrm{m}^{-3}$ the outcome is vastly different (Fig. 12b). Here, the by far largest number of blooms occurs for stronger upwelling-favourable winds $\left(\mathrm{UI}>0.25 \mathrm{~m}^{2} \mathrm{~s}^{-1}\right.$ ) (31 out of 64 events or $\left.48.4 \%\right)$. Half of these 31 events occur during low river discharges, which is characteristic of the austral summer season. Note that the proportion of such phytoplankton blooms increases from 48.4 to $69 \%$ when accounting for upwelling-favourable wind events with UI $>0.25 \mathrm{~m}^{2} \mathrm{~s}^{-1}$ in preceding data segments. Hence, more than two thirds of the phytoplankton blooms on the western Tasmanian shelf can be attributed to the classical wind-driven upwelling mechanism. The remaining events are mainly associated with October spring blooms, which are regular features of the study region (see Fig. 10b).

While the outcome from the viewpoint of phytoplankton blooms gives conclusive results, there are a total of 145 events with $\mathrm{UI}>0.25 \mathrm{~m}^{2} \mathrm{~s}^{-1}$ during the study period of which only $39(22 \%)$ triggered a phytoplankton bloom with chlorophyll $a$ concentrations exceeding $1.5 \mathrm{mg} \mathrm{m}^{-3}$. Another 13 events follow when accounting for UI values of the preceding data segment, which brings the total to $30 \%$. A number of possible processes could explain these missing phytoplankton blooms including (a) interference with river plumes that operate to suppress phytoplankton blooms, (b) lack of sufficiently long periods of relaxed wind after upwelling events (Wilkerson et al., 2006), (c) preceding downwelling periods that create a southward geostrophic coastal current and offshore transport in the bottom Ekman layer that, due to inertia effects, resist subsequent wind changes, (d) incursions of nutrient-poor water from the South Australian Current and (e) nutrient limitation. A more detailed analysis of possible causes of the missing blooms is beyond the scope of this study.

In order to compare phytoplankton productivity between the Bonney upwelling system and the western Tasmanian shelf, the author assumes that the spatial extent of their productivity zones is similar (see Figs. 3 and 8), and that 8day composite values of reconstructed chlorophyll $a$ concentration are proportional to the amount of phytoplankton formed during the 8-day period. This comparison is justifiable given (a) the relatively close proximity of the upwelling centres (which implies that the source properties of upwelled water are similar), (b) similar SST values during upwelling events (indicating similar upwelling intensities) and (c) similar values of FLH during upwelling events (indicating a sim- 
Table 2. Number of invalid events (cloud bias) of the time series (1 January 2005 to 31 March 2014) grouped according to different intervals of upwelling index (UI) and river discharge $(R)$.

\begin{tabular}{lrrrrr}
\hline$\downarrow R\left(\mathrm{~m}^{3} \mathrm{~s}^{-1}\right) / \mathrm{UI}\left(\mathrm{m}^{2} \mathrm{~s}^{-1}\right) \rightarrow$ & $<-1 / 4$ & $-1 / 4$ to 0 & 0 to $+1 / 4$ & $>+1 / 4$ & all $\mathrm{UI}$ \\
\hline$<25$ & 3 & 5 & 8 & 12 & 28 \\
25 to 50 & 4 & 5 & 6 & 14 & 29 \\
$>50$ & 35 & 3 & 5 & 9 & 52 \\
all $R$ & 42 & 13 & 19 & 35 & $\Sigma=109$ \\
\hline
\end{tabular}

Table 3. Relative production $\left(\mathrm{mg} \mathrm{m}^{-3}\right.$ ) for the Bonney coast and the western Tasmanian shelf (1 January 2005 to 31 March 2014 ) for different chlorophyll $a$ thresholds.

\begin{tabular}{lrrr}
\hline Criterion & Bonney coast & western Tasmanian shelf & \% of Bonney coast \\
\hline All events & 355.4 & 289.3 & $81.4 \%$ \\
Events with chl $a>1.5 \mathrm{mg} \mathrm{m}^{-3}$ & 180.0 & 126.4 & $70.2 \%$ \\
Events with chl $a>2.0 \mathrm{mg} \mathrm{m}^{-3}$ & 108.0 & 48.8 & $45.2 \%$ \\
Events with chl $a>2.5 \mathrm{mg} \mathrm{m}^{-3}$ & 79.1 & 31.1 & $39.3 \%$ \\
\hline
\end{tabular}

ilar phytoplankton growth rate on the timescale of upwelling events).

To this end, relative production can be defined as the time integral of 8-day composite chlorophyll $a$ values. This assumption gives a total of $289 \mathrm{mg}$ (per unit volume) in relative production for the western Tasmanian shelf (Table 3), which is about $81.4 \%$ of the relative production of the Bonney upwelling region. When only counting phytoplankton blooms with chlorophyll $a$ concentrations $>1.5 \mathrm{mg} \mathrm{m}^{-3}$, the western Tasmanian shelf still accounts for $70 \%$ of the relative production of the Bonney upwelling region. When considering exclusively rarer events of high chlorophyll $a$ concentrations $>2.5 \mathrm{mg} \mathrm{m}^{-3}$, the relative productivity of the western Tasmanian shelf reduces to $40 \%$ with reference to the Bonney upwelling region.

\section{Conclusions}

A detailed analysis of satellite-derived ocean colour data for the periods 1998-2000 and 2005-2014 suggest that the western Tasmanian shelf accommodates a highly productive ecosystem. This region forms another significant seasonal upwelling centre of the Great South Australian Coastal Upwelling System which develops in late austral summer (March-April). The addition of this newly discovered upwelling centre, which the author refers to as West Tasmanian Upwelling, makes the Great South Australian Coastal Upwelling System one of the largest (total spatial extension $\sim 1500 \mathrm{~km}$ ) seasonal coastal upwelling systems on Earth.

River plumes appear on the western Tasmanian shelf throughout the year, but continental runoff is markedly reduced during the upwelling season. Overall, there is no indication that river plumes contribute to primary production on the adjacent shelf, probably because of high concentrations of CDOM and suspended sediment (as indicated in OC-3 data) and the associated reduction in light levels. Interestingly, austral spring blooms develop regularly on the western Tasmanian shelf in October each year, but the reasons behind this development remains unclear.

The accuracy of satellite radar altimeter sea surface height measurement degrades in coastal region (Roesler et al., 2013) and cannot be used to identify upwelling jets here. Nevertheless, classical upwelling theory suggests the existence of such jets on the western Tasmanian shelf. The significance of these upwelling jets is that they operate to disperse nutrientrich water northward along the shelf and possible into western Bass Strait. This advective process would explain elevated chlorophyll $a$ levels in western Bass Strait - a typical feature of the region during austral summer months (see Fig. 3a). As such, upwelling on the western Tasmanian shelf presumably constitutes an important nutrient source for western Bass Strait waters.

The findings presented in this work were solely based on satellite data. Additional field work is required to explore the phytoplankton dynamics and potential differences between the upwelling centres off the Bonney coast and the western Tasmanian shelf in more detail.

Acknowledgements. The author thanks Paul Sandery (Bureau of Meteorology, Australia) for the provision of Cape Grim wind data and Emlyn Jones (CSIRO, Australia), who pointed out the unreliability of NASA-OC3 data for the western Tasmanian shelf. The author is also grateful to Piers Chapman and an anonymous reviewer for useful comments that improved the quality of the paper. This work has not received external funding. The author declares that there is no conflict of interests regarding the publication of this paper.

Edited by: M. Hoppema 


\section{References}

Behrenfeld, M. J., Westberry, T. K., Boss, E. S., O’Malley, R. T., Siegel, D. A., Wiggert, J. D., Franz, B. A., McClain, C. R., Feldman, G. C., Doney, S. C., Moore, J. K., Dall'Olmo, G., Milligan, A. J., Lima, I., and Mahowald, N.: Satellite-detected fluorescence reveals global physiology of ocean phytoplankton, Biogeosciences, 6, 779-794, doi:10.5194/bg-6-779-2009, 2009.

Chen, C., Zhu, J., Beardsley, R. C., and Franks, P. J. S.: Physical-biological sources for dense algal blooms near the Changjiang River, Geophys. Res. Lett., 30, 1515, doi:10.1029/2002GL016391, 2003.

Conolly, J. R. and Von der Borch, C. C.: Sedimentation and physiography of the sea floor south of Australia, Sediment. Geol., 1, 181-220, doi:10.1016/0037-0738(67)90059-0, 1967.

Cresswell, G.: Currents of the continental shelf and upper slope of Tasmania, Papers and Proceedings of the Royal Society of Tasmania, 133, 21-30, 2000.

Garcia, V. M. T., Signorini, S., Garcia, C. A. E., and McClain, C. R.: Empirical and semianalytical chlorophyll a algorithms in the southwestern Atlantic coastal region (25-40 $\mathrm{S}$ and $60-45^{\circ} \mathrm{W}$ ), Int. J. Remote Sens., 27, 1539-1562, 2006.

Gibbs, C. F., Tomczak, M., and Longmore, A. R.: The nutrient regime of Bass Strait, Aust. J. Mar. Fresh. Res., 37, 451-466, 1986.

Gitelson, A.: Algorithms for remote-sensing of phytoplankton pigments in inland waters, Adv. Space Res., 13, 197-201, 1993.

Gordon, H. R.: Diffuse reflectance of the ocean: the theory of its augmentation by chlorophyll a fluorescence at $685 \mathrm{~nm}$, Appl. Optics, 18, 1161-1166, 1979.

Gower, J. and King, S.: Validation of chlorophyll a fluorescence derived from MERIS on the west coast of Canada, Int. J. Remote Sens., 28, 625-635, 2007.

Gower, J. F. R.: A simpler picture of satellite chlorophyll fluorescence, Remote Sens. Lett., 5, 583-589, doi:10.1080/2150704X.2014.940630, 2014.

Gower, J. F. R., Brown, L., and Borstad, G. A.: Observation of chlorophyll a fluorescence in west coast waters of Canada using the MODIS satellite sensor, Can. J. Remote Sens., 30, 17-25, 2004.

Griffin, D. A., Thompson, P. A., Bax, N. J., and Hallegraeff, G. M.: The 1995 mass mortality of pilchards: no role found for physical or biological oceanographic factors in Australia, Aust. J. Mar. Fresh. Res., 48, 27-58, 1997.

Herzfeld, M.: The annual cycle of sea surface temperature in the Great Australian Bight, Prog. Oceanogr., 39, 1-27, doi:10.1016/S0079-6611(97)00010-4, 1997.

Kämpf, J.: On the preconditioning of coastal upwelling in the eastern Great Australian Bight, J. Geophys. Res.-Oceans, 115, C12071, doi:10.1029/2010JC006294, 2010.

Kämpf, J., Doubell, M., Griffin, D., Matthews, R. L., and Ward, T. M.: Evidence of a large seasonal coastal upwelling system along the southern shelf of Australia, Geophys. Res. Lett., 31, L09310, doi:10.1029/2003GL019221, 2004.

Lewis, R. K.: Seasonal upwelling along the southeastern coastline of South Australia, Aust. J. Mar. Fresh. Res., 32, 843-854, 1981.

Mann, K. H. and Lazier, J. R. N.: Dynamics of Marine Ecosystems: Biological-Physical Interactions in the Oceans, Oxford, Blackwell Publishing Ltd., 2006.
Maritorena, S., Morel, A., and Gentili, B.: Determination of the fluorescence quantum yield by oceanic phytoplankton in their natural habitat, Appl. Optics, 39, 6725-6737, 2000.

Middleton, J. F., Arthur, C., van Ruth, P., Ward, T., McClean, J., Maltrud, M., Gill, P., and Middleton, S.: ENSO effects and upwelling along Australia's southern shelves, J. Phys. Oceanogr., 37, 2458-2477, 2007.

Neville, R. A. and Gower, J. F. R.: Passive remote sensing of phytoplankton via chlorophyll a fluorescence, J. Geophys. Res., 82, 3487-3493, 1977.

O’Reilly, J. E., Maritorena, S., O'Brien, M. C., Siegel, D. A., Toole, D., Menzies, D., Smith, R. C., Mueller, J. L., Mitchell, B. G., Kahru, M., Chavez, F. P., Strutton, P., Cota, G. F., Hooker, S. B., McClain, C. R., Carder, K. L., Muller-Karger, F., Harding, L., Magnuson, A., Phinney, D., Moore, G. F., Aiken, J., Arrigo, K. R., Letelier, R., and Culver, M.: Ocean color chlorophyll a algorithms for SeaWiFS, OC2, and OC4: Version 4, in: SeaWiFS postlaunch calibration and validation analyses: Part 3, edited by: Hooker, S. B. and Firestone, E. R., 11, 9-23, SeaWiFS Postlaunch Technical Report Series, NASA Goddard Space Flight Center, 2000.

Rao, C. P. and Adabi, M. H.: Carbonate minerals, major and minor elements and oxygen and carbon isotopes and their variation with water depth in cool, temperate carbonates, western Tasmania, Australia, Mar. Geol., 103, 249-272, doi:10.1016/00253227(92)90019-E, 1992.

Rao, C. P. and Green, D. C.: Oxygen- and carbon-isotope composition of cold shallow-marine carbonates of Tasmania, Australia, Mar. Geol., 53, 117-129, doi:10.1016/0025-3227(83)90037-3, 1983.

Ridgway, K. R. and Condie, S. A.: The 5500-km-long boundary flow off western and southern Australia, J. Geophys. Res.Oceans, 109, c04017, doi:10.1029/2003JC001921, 2004.

Rochford, D. J.: A review of possible upwelling situation off Port MacDonald, South Australia, CSIRO Australian Division Oceanography Report No. 81, 4 pp., 1977.

Roesler, C. J., Emery, W. J., and Kim, S. Y.: Evaluating the use of high-frequency radar coastal currents to correct satellite altimetry, J. Geophys. Res.-Oceans, 118, 3240-3259, doi:10.1002/jgrc.20220, 2013.

Sandery, P. A. and Kämpf, J.: Winter-Spring Flushing of Bass Strait, South-Eastern Australia: A numerical modelling study, Est. Coast. Shelf Sci., 63, 23-31, doi:10.1016/j.ecss.2004.10.009, 2005.

Sandery, P. A. and Kämpf, J.: Transport timescales for identifying seasonal variation in Bass Strait, south-eastern Australia, Estuar. Coast. Shelf S., 74, 684-696, doi:10.1016/j.ecss.2007.05.011, 2007.

Sauer, M. J., Roesler, C. S., Werdell, P. J., and Barnard, A.: Under the hood of satellite empirical chlorophyll a algorithms: revealing the dependencies of maximum band ratio algorithms on inherent optical properties, Opt. Express, 20, 20920-20933, 2012.

Schahinger, R. B.: Structure of coastal upwelling events observed off the southern coast of South Australia during Feb 1983-April 1984, Aust. J. Mar. Fresh. Res., 38, 439-459, 1987.

Shanmugam, P.: A new bio-optical algorithm for the remote sensing of algal blooms in complex ocean waters, J. Geophys. Res., 116, C04016, doi:10.1029/2010JC006796, 2011. 
Tilburg, C. E., Subrahmanyam, B., and O'Brien, J. J.: Ocean color variability in the Tasman Sea, Geophys. Res. Lett., 29, 125.1125.4, doi:10.1029/2001GL014071, 2002.

Tomczak, M.: The Bass Strait water cascade during winter 1981, Cont. Shelf Res., 2, 55-87, 1985.

Volpe, G., Santoleri, R., Vellucci, V., Ribera d'Alcala, M., Marullo, S., and D'Ortenzio, F.: The colour of the Mediterranean Sea: Global versus regional bio-optical algorithms evaluation and implication for satellite chlorophyll estimates, Remote Sens. Environ., 107, 625-638, 2007.

Ward, T. M., McLeay, L. J., Dimmlich, W., Rogers, A., McClatchie, S., Matthews, R. L., Kämpf, J., and Van Ruth, P. D.: Pelagic ecology of a northern boundary current system: effects of upwelling on the production and distribution of sardine (Sardinops sagax), anchovy (Engraulis australis) and southern bluefin tuna (Thunnus maccoyii) in the Great Australian Bight, Fish. Oceanogr., 15, 191-207, doi:10.1111/j.1365-2419.2006.00353.x, 2006.
Wass, R. E., Connolly, R. J., and Maclntyre, R. J.: Bryozoan carbonates and sand continuous along southern Australia, Mar. Geol., 9, 63-73, doi:10.1016/0025-3227(70)90080-0, 1970.

Wilkerson, F. P., Lassiter, A. M., Dugdale, R. C., Marchi, A., and Hogue, V. E.: The phytoplankton bloom response to wind events and upwelled nutrients during the CoOP WEST study, Deep Sea Res.-Pt. II, 53, 3023-3048, 2006.

Xing, X.-G., Zhao, D.-Z., Liu, Y.-G., Yang, J.-H., Xiu, P., and Wang, L.: An overview of remote sensing of chlorophyll fluorescence, Ocean Sci. J., 42, 49-59, doi:10.1007/BF03020910, 2007. 